\title{
Spatial distribution of earthworms in natural and disturbed savannas of the Eastern plains of Colombia
}

\author{
Juan J. Jiménez ${ }^{\dagger 1}$, J.-P. Rossi ${ }^{\ddagger}$ and P. Lavelle \\ ${ }^{\dagger}$ Soil and Plant Nutrition Unit. CIAT. AA 6713. Cali, Colombia. \\ *aboratoire d'Ecologie et Biologie des Sols Tropicaux. Université Pierre et Marie Curie, \\ centre IRD d'île de France. 32 Av. Henri Varagnat, 93143. Bondy cedex, France.
}

${ }^{1}$ Corresponding author

Phone: 5724450000

Fax: 5724450073

E-mail: j.jimenez@cgiar.org

Complete correspondence address:

Soil and Plant Nutrition Unit

Centro Internacional de Agricultura Tropical (CIAT)

AA 6713

Cali

Colombia 


\footnotetext{
1 Abstract

2 The horizontal spatial distribution of earthworms in a native savanna and in a 17-yr

3 introduced pasture from the area of Carimagua (Colombia) was assessed by means of

4 aggregation indices and geostatistical analysis. Morisita's $\mathrm{I}_{\mathrm{d}}$ and Taylor $b$ indices were

5 calculated from field data obtained through $1 \mathrm{~m}^{2}$ quadrats during a sampling period of 17

6 months and both semivariograms and contour maps were obtained at three different dates

7 through a rapid sampling of $6440 \times 40 \times 15-\mathrm{cm}$ soil blocks regularly distributed in the nodes

8 of a $8 \times 8$ grid (i.e. $70 \times 70 \mathrm{~m}$ ). Earthworms tended to exhibit contagious distribution in both

9 land use systems and a multivariate relationship appeared between the size of the

10 earthworm and aggregation indices employed. Land use had no significant effect on the

11 spatial distribution of earthworms. Earthworms belonging to different ecological categories

12 and from diverse sizes were spatially distributed in patches of several tens of meters.

13 Semivariograms reflected, occasionally, the size of these patches although no spatial

14 structure was perceived at some dates. This might be due to the intersample distance

15 employed $(10 \mathrm{~m})$ so that changing the scale of observation could reflect unseen patterns.

16 In this study our purpose was first to determine the strength of spatial aggregation in some

17 Neotropical earthworm species and then to observe the movement of population patches at

18 the scale of the studied area. The use of these types of spatial analyses in conjunction may

19 be very useful to establish the dynamics of earthworm populations in the field.

21 Key words: Spatial distribution, Geostatistics, Principal Component Analysis, Aggregation

22 index, Population ecology, Savannas 


\section{Introduction}

There have been many recent studies on the abundance and spatial distribution of several animal taxa in soils. Geostatistical analysis has been used to assess the spatial distribution of microorganisms and Collembola (Fromm et al. 1993), nematodes (Wallace and Hawkins 1994, Robertson and Freckman 1995, Delaville et al. 1996, Rossi et al. 1996, Ettema et al. 1998) and earthworms (Poier and Richter 1992, Stein et al. 1992, Rossi et al. 1995, 1997).

Although earthworm distribution is known to be irregular and aggregated (Guild 1955, Satchell 1955, Svendsen 1957), a first attempt to quantify the spatial pattern on earthworm populations was initiated by Phillipson et al. (1976) and it has been followed by Lavelle (1978; 1983a; 1988), Fragoso (1993), Boag et al. (1994), Rossi (1998), Rossi et al. (1995; 1997), Rossi and Lavelle (1998), and Decaëns and Rossi (in press) in more detail. These studies indicated that soil fauna was generally spatially structured at small scales (<100m) (Robertson 1994).

Little is known about the factors that control or influence the observed spatial patterns of soil macrofauna. Presumably, abiotic factors are responsible at least partly, for the spatial pattern of these soil macroinvertebrates. However, several studies have shown a lack of relationship between soil abiotic factors and the spatial pattern of various taxa of invertebrates. For example, Rossi et al. (1997) showed that the distribution of the endogeic megascolecid earthworm Polypheretima elongata Perrier was independent of a strong gradient in soil organic matter, their food resource. Ettema et al. (1998), in a study on spatiotemporal dynamics of bacterivorous nematodes, demonstrated the lack of correlation between nematode and soil resource patterns, although they explained it by the young age of the investigated plots. At a given scale, organisms may appear to be distributed in relation to some abiotic factors (e.g. soil texture and plant-parasitic nematodes [Wallace et al. 1993]) though Rossi and Quénéhervé (1998) showed that these kind of correlations might be spurious in some cases. Generally, species distributional patterns are likely to be controlled by many factors acting at different scales both in time and space. 
The spatial distribution of soil organisms is influenced, among other factors, by the plant cover, resulting in a horizontal mosaic of areas subjected to gradients of nutrient availability and microclimatic conditions (Lavelle 1983b). Such a pattern is probably more pronounced in savanna ecosystems than in any other, because of the strong seasonality affecting both temperature and moisture gradients. On the other hand, land use systems and agricultural practices, have been shown to directly affect soil resource patchiness (Robertson et al. 1993). In turn, a change in soil resource heterogeneity is supposed to have huge potential effect on plant community structure and the distribution of soil living organisms (Tilman 1988). Plant community composition may be itself determined by the type of agricultural practice and soil nutrient status (Miles 1985; Wardle and Lavelle 1997). Furthermore, if plant community influences, for example, termite and earthworm assemblage composition (Lavelle et al. 1997), it should also be affecting their spatial distribution. The impact of these organisms in soil functioning is obviously conditioned by the per capita effect but also by the spatial location of the individuals. This is a relevant feature when the effects of ecosystems engineers (sensu Jones et al. 1994) are assessed.

The aim of this work was to examine the potential effect of changing a natural savanna into improved pasture by planting African grass and tropical herbaceous legume species, combined with grazing, upon spatial distribution of earthworms and their morphological traits. We also tested the relationship between spatial distribution and morphological parameters according to land use, and the suitability of geostatistical techniques for description of earthworm distribution with the intersample distance used.

We estimated different aggregation indices for earthworm species in a natural and a disturbed savanna in order to determine how disturbance could affect spatial distribution of populations. However, aggregation indices do not take into account the actual location of the sampling units and thus provide no information on the spatial distribution at scales larger than the sampling unit size (Rossi et al. 1995). We therefore intended to fully characterize the earthwom spatial distribution by designing a spatially explicit sampling scheme and processing the data using geostatistics. This method allows assessment of consistency of spatial patterns as well as the scale at which they are expressed (Robertson 1994). 

well-drained isohyperthermic savannas of the Eastern Plains of Colombia $\left(4^{\circ} 37^{\prime} \mathrm{N}\right.$ and $71^{\circ}$

\subsection{Site description}

The study was undertaken at the CIAT-CORPOICA Carimagua field station, in the 19 ' W) at 175 meters altitude. Average yearly rainfall is $2280 \mathrm{~mm}$ with a mean temperature of $26^{\circ} \mathrm{C}$, and a dry season from December to March. Soils are of two types: low-fertility Oxisols in the upland ("altos") and Ultisols in the low-lying ("bajos") savannas. The former are characterised by their acidity ( $\mathrm{pH} 4.5$, water), a high Al saturation (> 90\%) and low values of exchangeable $\mathrm{Ca}, \mathrm{Mg}$ and $\mathrm{K}$.

Two different and contrasting paddocks were investigated: A native savanna without grazing nor burning where Andropogon bicornis, Gymnopogon sp., Panicum spp., Trachypogon spp. and Imperata sp. are the most abundant plant species, and a 17-yr old grazed pasture, in a two ha plot, that combines an exotic African grass, Brachiaria $\underline{\text { decumbens }}$ cv. Basilisk, and a tropical herbaceous legume, Pueraria phaseoloides CIAT 9900 (“Kudzu”).

\subsection{Earthworm biology background}

In the investigated paddocks, the earthworm community is comprised of eight species, all natives and present in the introduced system (Jiménez et al. 1998b). Most species belong to family Glossoscolecidae, the most widespread earthworm family in the neotropical region, Andiodrilus sp. (endogeic mesohumic), Andiorrhinus sp. (endoanecic), Andiorrhinus sp. 2 (endoanecic?), Aymara sp. (epigeic), Glossodrilus sp. (endogeic polyhumic) and Martiodrilus carimaguensis (anecic), and two new genera belonging to the families Ocnerodrilidae (endogeic polyhumic) and Acanthodrilidae (epigeic) (unpublished data). There are major differences in the structure of the earthworm communities in the 
114

115

116

117

118

119

120

121

122

123

124

125

126

127

128

129

130

131

132

133

134

135

136

137

138

139

140

141

142

143

savanna and pasture plots. In the savanna endogeic species make up $83.2 \%$ of the total biomass, ca. $3.26 \mathrm{~g}$ fresh weight $\mathrm{m}^{-2}$, Glossodrilus sp. being the most abundant species, whereas in the pasture, several endogeic species represent only $12 \%$ of the total earthworm biomass, $57.1 \mathrm{~g}$ f.w. $\mathrm{m}^{-2}$, and the anecic species accounts for $88 \%$ of total biomass (Jiménez et al. 1998b).

\subsection{Earthworm sampling}

Two sampling strategies were used in this study:

1) Monthly sampling: A stratified random sampling procedure was performed during 17 months (from April 1994 to September 1995, except June 1994) in both systems. Earthworms were monthly handsorted from 1x1x0.5 m monoliths (Lavelle 1978) in each system and carried to the laboratory where length $(\mathrm{mm})$, preclitelar diameter $(\mathrm{mm})$ and weight $(\mathrm{g})$ were measured.

2) Spatially explicit sampling: In both plots, 64 points distributed in the nodes of a regular 70x70-m grid were sampled for earthworm analysis. A soil monolith of 40x40x15 $\mathrm{cm}$ was rapidly taken in each point and handsorted in order to count all the earthworm species and their different demographic categories: adults (with clitellum and sexual protuberances), juveniles (subadults, sexual protuberances present but no clitellum and immatures, neither clitellum nor sexual protuberances) and cocoons. The method, following Rossi and Lavelle (1993) was adapted due to the large size of M. carimaguensis. All the earthworms were later replaced into the soil at their original places in the grid. To avoid sampling at the same points in the different dates samples were displaced along a spiral whose origin was represented by the point sampled at the first date. With respect to the size of the paddocks we considered as identical the sampling points from one date to another. The two plots studied were surveyed at three different times: November 1993, November 1994 and May 1995, for the native savanna, and September 1993, October 1994 and June 1995 for the grass-legume pasture. 
144

145

146

147

148

149

150

151

152

153

154

155

156

157

158

159

160

161

162

163

164

165

166

167

168

169

170

171

172

\subsection{Data analysis}

\subsubsection{Aggregation indices}

As a first attempt to determine the spatial pattern of earthworms, two aggregation indices were computed: Morisita $\mathrm{I}_{\mathrm{d}}(1959)$ and Taylor $b$ (1961).

1) Comparing spatial aggregation of populations with very different mean densities requires an index insensitive to mean density. Morisita $(1959,1971)$ proposed an index of aggregation independent on the sample mean and the total number of individuals in samples $\left(\sum \mathrm{x}\right)$. However, this index is strongly related to the total number of sampling units. It is defined as:

$$
\mathrm{I}_{\delta}=\mathrm{n}\left(\sum_{\mathrm{i}=1}^{\mathrm{n}}\left(\mathrm{Z}_{\mathrm{i}}^{2}\right)-\sum_{\mathrm{i}=1}^{\mathrm{n}} \mathrm{Z}_{\mathrm{i}}\right) /\left(\left(\sum_{\mathrm{i}=1}^{\mathrm{n}} \mathrm{Z}_{\mathrm{i}}\right)^{2}-\sum_{\mathrm{i}=1}^{\mathrm{n}} \mathrm{Z}_{\mathrm{i}}\right)
$$

Where $\mathrm{n}$ is the number of sampling units and $\mathrm{Z}_{\mathrm{i}}$ the count for the ith sampling unit.

The Morisita's index equals 1 for random distributions, is less than 1 for regular distributions and greater than 1 for clumped distributions. Departure from randomness can be statistically tested by comparison to a chi-square $\left(\chi^{2}\right)$ value (Elliot 1971).

2) The Taylor's Power Law (Taylor 1961, 1984; Taylor et al. 1978) is based on the empirical relationship between the mean $(\mathrm{m})$ and the variance $\mathrm{s}^{2}$ that are related by the exponential function:

$$
s^{2}=a m^{b}
$$

The parameters $a$ and $b$ are population parameters. $b$ is considered to be an intrinsic measure of population aggregation varying continuously from zero for regular distribution 
$173\left(s^{2}=a\right.$ with $\left.a<1\right)$ through 1 for random distribution $\left(s^{2}=m\right.$ with $\left.a=1\right)$ to $\infty$ for strongly 174 contagious distribution (Taylor 1961).

175 The parameter $a$ is a scaling factor depending on the size of the sample unit (Taylor 1961; Elliot 1971) and the exponent $b$ is used as an aggregation index. $b$ is assumed to be independent of the mean so that it is a value measuring aggregation without being confused by changes in population mean density (Taylor 1961; 1984; Taylor et al. 1988).

The parameters $a$ and $b$ are determined by linear regression of sample means and variances after the mean and variance estimates are log-transformed:

$$
\log s^{2}=\log a+b \log m
$$

The Taylor's Power Law aggregation index is assumed to be species-specific (Taylor $1961 ; 1988)$ and has been shown to be closely related to life history traits of various African earthworm species (Rossi and Lavelle 1998).

\subsubsection{Principal Component Analysis}

A Principal Component Analysis (Webster and Oliver 1990) was performed to examine the relationships between several biological traits, i.e. adult weight (AW), adult length (AL), immature weight (IW), immature length (IL), length/width ratio (L/W), weight/width ratio (W/W) and mean annual vertical distribution (VD) together with Morisita's and Taylor's Power Law indices. To determine if land use influences these variables, such as aggregation indices and biological traits, that were recorded for earthworm populations from the pasture and the natural savanna plots, they were analysed together.

\subsubsection{Geostatistics} tool to describe any spatially structured variable in the soil. Central to geostatistics is the 
semi-variogram, the function which describes the evolution of the semi-variance with the inter-sample distance (Webster and McBratney 1989). It is the single most important tool in geostatistical applications to soil (McBratney and Webster 1986). In the regionalized variable theory the quantity $\gamma(h)$ is known as the semi-variance and it is estimated using the algorithm:

$$
\gamma(\mathrm{h})=1 / 2 M(\mathrm{~h}) \sum_{\mathrm{i}=1}^{M(\mathrm{~h})}\left\{\left[\mathrm{Z}\left(x_{i}\right)-\mathrm{Z}\left(x_{i}+\mathrm{h}\right)\right]^{2}\right\}
$$

Where $M(\mathrm{~h})$ is the number of sample pairs at each distance interval $\mathrm{h}$ ("lag") and $\mathrm{Z}\left(x_{\mathrm{i}}\right)$ and $\mathrm{Z}\left(x_{\mathrm{i}}+\mathrm{h}\right)$ the values of the variable at any two places separated by a distance $\mathrm{h}$.

The semi-variogram is the plot of the semi-variance against the distance (lag). Its shape indicates whether the variable is spatially dependent or not, e.g. there is spatial autocorrelation. The more alike the values separated by a given distance, the lower the semi-variance. Thus generally the semi-variance increases with increasing distance as similarity between points decreases. If the variable is not spatially dependent, the semivariance fluctuates around the sample variance and the semi-variogram is "flat".

Estimated values of the semivariance are adjusted to a theoretical model (McBratney and Webster 1986; Webster and Oliver 1990; Rossi et al. 1995), which is fitted to the semivariogram calculated from sample values. Generally, only several authorized functions are used in semi-variogram modelling (see Webster 1985 and Rossi et al. 1995 for a reviewand the models normally used). In the case of spatial autocorrelation, when the lag distance is increased the semi-variance gets to a maximum value (the "sill" variance) for a given distance interval (the range). In the semivariogram the range marks the limit of the spatial dependence or autocorrelation in the variable concerned. For distances larger than the range the semi-variance remains fixed leading to a plateau in the semi-variogram. The intercept of the semi-variogram is generally a non-zero value called the nugget variance $(\mathrm{C} 0)$ that expresses the variability due to unseen patterns (occurring at scales shorter than minimum inter-sample distance). The sill variance minus the nugget variance is the spatial variance 
232 (C). This term accounts for the part of the total variance that can be modeled by the spatial 233 structure (McBratney and Webster 1986).

234

Semivariograms were estimated using the software VAR 5 (Yost et al. 1989), which allows semivariogram estimation and model fitting by a modified least square differences procedure (Cressie 1985).

\section{Contour maps}

Classical contour maps were plotted using the command "contour plot" of the software Sigma plot 4.0.

\section{Results}

Density of earthworms varied both among species and dates in relation to geostatistical sampling. In both systems the highest abundance was obtained for Glossodrilus sp. In the savanna numbers ranged from 18.9 (November 1994) to 46.3 individuals $\mathrm{m}^{-2}$ (November 1993), and from 36.9 (1994) to 102.5 ind $\mathrm{m}^{-2}$ (1995) in the pasture. The epigeic species Aymara sp. was only obtained in 1995 sampling where the density of this species was 7.81 and 13.5 ind $\mathrm{m}^{-2}$ in the savanna and pasture, respectively. The density obtained for $\underline{\mathrm{M} \text {. carimaguensis }}$ and Andiorrhinus $\mathrm{sp}$. was less than 1 ind $\mathrm{m}^{-2}$, except for the former in 1995 in the pasture plot $\left(14.5\right.$ ind $\left.\mathrm{m}^{-2}\right)$. Values of density for Ocnerodrilidae n. gen $n$. sp. were also very low; in the savanna the abundance of this species varied from 2 ind $\mathrm{m}^{-2}$ in 1993 to 7 ind $\mathrm{m}^{-2}$ in 1995 and in the pasture from 6.6 to 18.8 ind $\mathrm{m}^{-2}$ in 1994 and 1995, respectively. Finally, the numbers of Andiodrilus sp. varied from 1.97 ind $\mathrm{m}^{-2}$ in 1993 to 2.7 ind $\mathrm{m}^{-2}$ in 1995 in the savanna and from 3.5 (1993) to 6.2 (1995) in the pasture. Tables 1 and 2 summarize the data obtained for the different demographic stages of all species in the savanna and pasture, respectively.

Earthworm species tended to exhibit clumped spatial distributions. Indices $\mathrm{I}_{\mathrm{d}}$ and $b$ showed a strong aggregation for all species in both systems (Table 3). All regression 
coefficients were significant at $1 \%$ in both systems except for the anecic $\underline{\mathrm{M} \text {. carimaguensis }}$

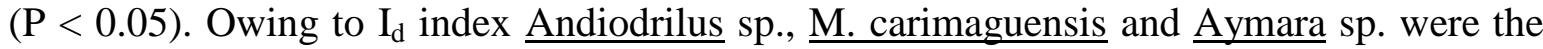
most aggregated species in the savanna, whereas in the pasture the highest aggregation appeared for Andiodrilus sp., Andiorrhinus sp. and Aymara sp. All the values were statistically different from 1 , as given by the $\chi^{2}$ test.

The PCA showed general multivariate relationships between the size of earthworm and aggregation (Fig. 1). The first two axes accounted for respectively 57.6 and $22.1 \%$ of the total inertia. Axis 1 was defined by the yearly average vertical distribution and biometric variables, except L/W ratio. Axis 2, on the other hand, separates the former ratio and both aggregation indices. Axis 1 segregated larger species living at great depth $(\underline{M}$. carimaguensis) from those smaller living near the soil surface, whereas axis 2 separated those species with higher L/W ratio (Glossodrilus sp.) from those species with a more contagious distribution and lesser L/W ratio (Andiodrilus sp.). The effect of land use was not significant except for the variable annual vertical depth $(\mathrm{T}$-test, $\mathrm{P}=0.0123)$. The pattern of species upon factorial axes 1 and 2 (Fig. 2) revealed that land use was of no consistent effect so that the distribution of these species is to be explained by biological features.

The spatial structure of the demographical stages of the different earthworm species was only assessed in some semivariograms. This means that, in most cases, the intersample distance employed, i.e. $10 \mathrm{~m}$, was too large to allow a proper assessment of the spatial structure for this specific earthworm community. The aggregated patterns showed by aggregation indices are likely to be expressed beyond the scale of 10 meters in most of the cases we studied. When significant, most of the variograms were of spherical type (Fig. 3) and indicated that spatial variability was expressed at scales ranging from the 27.1 to 57.4 m. (Table 4).

In both systems earthworm population was spatially distributed in patches of ranging sizes from date to date. Species were aggregated in several patches of an average size of 30-40 m, sometimes greater. As an example, in September 1993 Glossodrilus sp. was mostly composed of juveniles in the pasture (Fig. 4). Two patches could be observed, one of them large placed on the left side of the plot and the other one located at the right corner somewhat smaller than the former. By June 1995 the whole population was made up 
of juveniles, since adults begin to appear at the end of the rainy season (Jiménez et al. 1998b). It was as if the large patch would have moved to the left and in the right corner two new patches were distinguished.

\section{Discussion}

Earthworms are organisms with a highly contagious spatial distribution (Rossi and Lavelle 1998). Our results agree with Piearce (1982) who found that, with independence of the aggregation index employed, earthworms were highly aggregated in soils of the north western coasts of England. Values for the Taylor $b$ index were very similar to those obtained by Taylor et al. (1978) who used data from Gerard (1960). In our study, the large value of $b$ index for Andiorrhinus sp. could be explained by means of its abundance in the systems studied. Hairston (1959, quoted in Lloyd 1967) concludes that aggregation indices are higher for rare species and Andiorrhinus sp. is a rare species in Carimagua (Jiménez et al. 1998b).

The evaluation of aggregation indices depends on the measurement scale and applies to all methods that quantify the spatial variance of the distribution of any organism (Horne and Schneider 1995). Curtis and Mcintosh (1950) and later Pielou (1969) and Greig-Smith (1983) demonstrated the dependence of several indices on the measurement scale. Hurlbert (1990) concluded, on the contrary, that it is an aggregation measure without interpretation. So, comparison of aggregation indices among populations are only valid when evaluated at the same spatial scale.

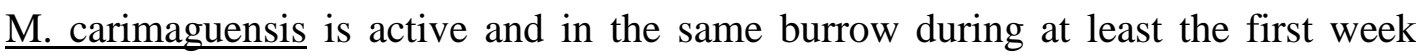
after cast deposition began (Jiménez et al. 1998a; Decaëns 2000). This species inhabits semi-permanent U-shaped vertical burrows (Jiménez and Decaëns, unpublished data) and is strongly influenced by seasonal patterns in climate. The burrow is normally abandoned after rain saturation that results in a depletion of $\mathrm{O}_{2}$ in the soil (Jiménez et al. 1998a). Maybe this kind of behaviour leads to the low values of $\mathrm{I}_{\mathrm{d}}$ index obtained in the pasture, and assessment of the distribution pattern of the different demographic stages, i.e. adults $v s$. immatures, would reveal unseen patterns. 
Both aggregation indices employed in this study provided useful tools to assess spatial pattern and its correlation with biological features, i.e. earthworm size. This type of relationship was also established in the case of earthworm community from an African savanna (Rossi and Lavelle 1998). These authors found that smaller species were strongly aggregated. At Carimagua species of medium to large size were more aggregated, so conclusions must be drawn carefully and other earthworm communities should be included in this type of analysis in order to establish the patterns that define the aggregation of species. A plausible explanation may be the absence of a true anecic species, like $\underline{\mathrm{M}}$. carimaguensis, in Lamto. We also agree with these authors that in order to define more precisely the ecological categories of earthworms this kind of analysis should be used, especially if $b$ index is species-specific as Taylor et al. (1988) stated.

Several factors may be responsible for the unsuccessful performing of geostatistical analysis:

1. Density: population density fluctuates seasonally due to environmental conditions. The number of earthworms at the end of the rainy season (1993 and 1994) is somewhat low for some species as they have already entered the inactivity period.

2. Size of species: sampling was carried out manually and not all the individuals are caught when hand-sorting method is applied. For several species, Aymara sp., Glossodrilus sp. and Ocnerodrilidae n. gen. n. sp., almost 50\% of the whole population is not collected when employing this method (Jiménez, unpublished data)

3. Size of sampling units: the size employed may not be so optimum as to get large anecic species as $\underline{M}$. carimaguensis which rapidly retreats deeper into its vertical burrow.

4. Intersampling distance: since populations display a clear aggregated spatial structure, at least at the scale of the sampling units, it is likely that the minimum intersample distance is too large to allow a clear assessment of the spatial distribution at scales larger than this value. Our results suggest that earthworms are aggregated in local spots less than 10-m diameter.

5. Mosaic structure: Martin (1991) hypothesised about the presence of

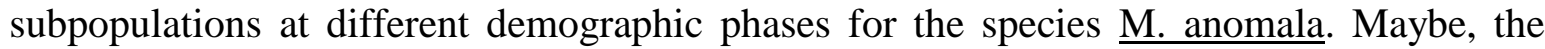


observed patterns in the earthworm community of both systems studied correspond to a spatiotemporal mosaic of population patches. But this hypothesis needs to be further tested.

The horizontal distribution patterns of earthworms are difficult to assess since they have been described on various scales, from local (Phillipson et al. 1976; Lavelle 1978) to regional (Evans and Guild 1948; Németh 1981) and geographical scale (Bouché 1972; Fragoso 1993). The spatial variability in the horizontal distribution of earthworms ranges from $1 \mathrm{~m}$ (Rossi 1998) to $50 \mathrm{~m}$ (Poier and Richter 1992). The tropical endogeic $\underline{\text { P. elongata }}$ Perrier is distributed in clumps of 20-30 m diameter, with a marked opposite pattern amongst adults and juveniles (Rossi et al. 1997). None of the demographic stages of this species were spatially autocorrelated with some soil variables, e.g. soil organic matter and clay gradients. In the study previously mentioned the authors explain the observed patterns on the basis of demographic processes, such as intraspecific competition that leads to decreasing fecundity in areas of high adult density. The size of patches coincides with those reported by Rossi et al. (1997) and Rossi and Lavelle (1998) for some savanna species from Lamto (Ivory Coast). Besides, the limits of the spatial distribution obtained in this study are within those described by Robertson (1994), below $100 \mathrm{~m}$.

Our sampling strategy employed was not very useful to assess adequately using geostatistics the spatial pattern of earthworm distribution, even though when species have been shown to be spatially aggregated (aggregation index values different from random). Aggregation is a characteristic of earthworm populations that was easy to demonstrate with both $\mathrm{I}_{\mathrm{d}}$ and $b$ indices, but a finer resolution must be carried out to show actual significant spatial patterning with geostatistics.

From our results we cannot conclude if the observed distribution is due to inner or external driving factors within the population. Rossi et al. (1997) assessed the spatial distribution of $\underline{P}$. elongata in market-flower gardens of Martinique Island by means of inner processes within the population. In other study Rossi and Quénéhervé (1998) found no significant relationship between both plant-feeding and free-living nematodes and several soil parameters in vertisols from the same site, except for the density of the plant-feeding nematode Helicotylenchus retusus Siddiqui and Brown which was negatively correlated with clay content. 
Disturbance plays a major role in structuring ecological systems as they create a spatiotemporal mosaic of patches. Moloney and Levin (1996) indicated that the spatial pattern of disturbance has in general been ignored, with attention only restricted to understanding the effects of both rate and intensity of disturbance. Studies on disturbance hardly have considered the spatial structure of the disturbance regime. In addition to this, the spatiotemporal dynamics of soil variables in disturbed systems, i.e. density of earthworms, have not been deeply studied despite of Rossi (1998; in press), Decaëns and Rossi (in press) and Jiménez (1999) who provide information on this subject.

In this paper we have showed the usefulness of the different statistical tools employed in the spatial analysis of earthworm populations. On the other hand, and interestingly enough, land-use practices in the disturbed ecosystem had no clear impacts on the horizontal spatial distribution of earthworms. This suppports the hypothesis that spatial distribution is determined by factors acting within the population itself, but it needs further research. In a next paper (Jiménez et al. unpublished) a brand new method to detect common spatial patterns across several sampling dates will show the stability and opposite distributions among different earthworm species.

\section{Acknowledgements}

This study was included within the Macrofauna Project from the STD-2 EC. The first author wants to thank CIAT (International Center for Tropical Agriculture) for technical and human support during all the study period. The first author acknowledges T. Decaëns and two anonymous referees for their helpful comments on earlier versions of this paper.

\section{References}

Boag B., Legg R. K., Neilson, R., Palmer, L.F. and Hackett, C.A., 1994. The use of Taylor's Power Law to describe the aggregated distribution of earthworms in permanent pasture and arable soil in Scotland. Pedobiologia 38, 303-306.

Bouché, M. B., 1972. Lombriciens de France. Ecologie et Systematique. I.N.R.A., Paris, 671 pp.

Cressie, N., 1985. Fitting variogram models by weighted least squares. Math. Geol. 17, 563-586. 
Curtis, J. T. and Mcintosh, R. P., 1950. The interrelation of certain analytic and synthetic phytosociological characters. Ecology 31, 434-455.

Decaëns, T., 2000. Degradation dynamics of surface earthworm casts in grasslands of the eastern plains of Colombia. Biol. Fertil. Soils 32, 149-156.

Decaëns, T. and Rossi, J.-P., Spatio-temporal structure of an earthworm community and soil heterogeneity in a tropical pasture (Carimagua, Colombia). Ecography (in press).

Delaville, L., Rossi, J.-P. and Quénéhervé P., 1996. Plant row and soil factors influencing the micro-spatial patterns of plant-parasitic nematodes on sugarcane in Martinique. Fund. Appl. Nem. 19 (4), 321-328.

Elliot, J. M., 1971. Some methods for statistical analysis of sampling of benthic invertebrates. Freshwater Biological Associates, The Ferry House, Ambleside, UK, 144 p.

Ettema, C. H., Coleman, D. C., Vellidis, G., Lowrance, R. and Rathbun, S. L., 1998. Spatiotemporal distribution of bacterivorous nematodes and soil resources in a restored riparian wetland. Ecology 79(8), 2721-2734.

Evans, A. C. and Guild, W. J. McL., 1948. Studies on the relationships between earthworms and soil fertility. IV. On the life cycles of some British Lumbricidae. Ann. Appl. Biol. 35, 471-484.

Fragoso, C., 1993. Les Peuplements de Vers de Terre dans L'Est et Sud-Est du Mexique. Thèse de Doctorat, Université Paris 6, $228 \mathrm{pp}+$ annexes.

Fromm, H., Winer, K., Filser, J., Hantschel, R. and Beese, F., 1993 The influence of soil type and cultivation system on the spatial distributions of the soil fauna and microorganisms and their interactions. Geoderma 60, 109-118.

Gerard, B. M., 1960. The biology of certain British earthworms in relation to environmental conditions. Ph. D. Thesis, London, UK.

Greig-Smith, P., 1983. Quantitative Plant Ecology. University of California Press, Berkeley, USA.

Guild, W. J. McL., 1955. Earthworms and soil structure. In: McKevan, D. K. (Ed). Soil Zoology. Butterworths, London. pp. 83-98.

Horne, J. K. and Schneider, D. C., 1995. Spatial variance in ecology. Oikos 74, 18-26.

Hurlbert, S. H., 1990 Spatial distribution of montane unicorn. Oikos 58, 257-271.

Jiménez, J. J., 1999 Estructura de las comunidades y dinámica de las poblaciones de lombrices de tierra en las sabanas naturales y perturbadas de Carimagua (Colombia). PhD Thesis, University Complutense. 311 p. (in spanish)

Jiménez, J. J., Rossi, J.-P., Decaëns, T., The spatiotemporal distribution of a earthworm community assemblage (in preparation)

Jiménez, J. J., Moreno, A. G., Lavelle, P. and Decaëns, T., 1998a. Population dynamics and adaptive strategies of Martiodrilus carimaguensis (Glossoscolecidae, Oligochaeta), a native species from the well-drained savannas of Colombia. Appl. Soil Ecol. 9 (1-3), 153-160. 
Jiménez, J. J., Moreno, A. G., Decaëns, T., Lavelle, P., Fisher, M. J. and Thomas, R. J., 1998b. Earthworm communities in native savannas and man-made pastures of the Eastern Plains of Colombia. Biol. Fertil. Soils 28 (1), 101-110.

Jones, C. G., Lawton, J. H., and Shachak, M., 1994. Organisms as ecosystem engineers. Oikos 69, 373-386.

Lavelle, P., 1978 Les vers de terre de la savane de Lamto (Côte d'Ivoire): peuplements, populations et fonctions dans l'ècosystème. Thèse de Doctorat, Paris VI. Publ. Lab. Zool. E.N.S., 12, 301 p.

Lavelle, P., 1983a. The structure of earthworm communities. In: Satchell, J. E. (Ed). Earthworm Ecology: From Darwin to Vermiculture. Chapman and Hall, London. pp. 449-466.

Lavelle, P., 1983b The soil fauna of tropical savannas.I. The community structure. In: Bourlière, F. (Ed). Tropical Savannas. Elsevier, Amsterdam. pp. 477-484.

Lavelle, P., 1988 Assesing the abundance and role of invertebrate communities in tropical soils: aims and methods. J. Afr. Zool. 102, 275-283.

Lavelle P., Bignell, D., Lepage, M., Wolters, V., Roger, P., Ineson, P., Heal, O.W. and Dhillion, S., 1997. Soil function in a changing world: the role of invertebrate ecosystem engineers. Eur. J. Soil Biol. 33(4), 159-193.

Lloyd, M., 1967. Mean crowding. J. Anim. Ecol. 36, 1-30.

Martin, S., 1991. Modélisation de la dynamique et du rôle d'une population de vers de terre Millsonia anomala dans les savanes humides de Côte d'Ivoire. Thèse de l'Université Paris VI.

Matheron, G., 1965. Les variables regionalisées et leur estimation. Masson, Paris. 305 p.

Matheron, G., 1971. The theory of regionalized variables and its application. Cashiers du Centre Morphologie Mathématique, $N^{\circ}$ 5. Fontainebleau, France.

McBratney, A. B. and Webster, R., 1986. Choosing functions for semivariograms of soil properties and fitting them to sampling estimates. J. Soil Sci. 37, 617-639.

Miles, J., 1985 Soil in the ecosystem. In: Atkinson, D. Fitter, A. H. Read, D. J. and Usher, M. B. (Eds). Ecological Interactions in Soil, Plants, Microbes and Animals. Blackwell Scientific Publications, Oxford, Great Britain. pp. 407-427

Moloney, K. A. and Levin, S. A., 1996. The effects of disturbance architecture on landscape-level population dynamics. Ecology 77(2), 375-394.

Morisita, M., 1959. Measuring of the dispersion of individual and analysis of distribution patterns. Mem. Fac. Sci. Kyushu Univ. Ser. E Biol. 2, 215-235.

Morisita, M., 1971. Composition of the $\mathrm{I}_{\mathrm{d}}$-index. Res. Popul. Ecol. Kyoto Univ. 13, 1-27.

Németh, A., 1981. Estudio ecológico preliminar de las lombrices de tierra (Oligochaeta) en ecosistemas de bosque húmedo tropical en San Carlos de Río Negro, Territorio Federal Amazonas. Tesis de grado, Universidad Central de Venezuela. 92 p. (in spanish)

Phillipson, J., Abel, R., Steel, J.and Woodell, S. R. J., 1976. Earthworms and the factors governing their distribution in an English beechwood. Pedobiologia 16, 258-285. 
Piearce, T. G., 1982. Recovery of earthworm populations following salt-water flooding. Pedobiologia 24, 91100 .

Pielou, E. C., 1969. An Introduction to Mathematical Ecology. John Wiley, New York, USA.

Poier, K. R. and Richter, J., 1992. Spatial distribution of earthworms and soil properties in an arable loess soil. Soil Biol. Biochem. 24, 1601-1608.

Robertson, G. P., 1994. The impact of soil and crop management practices on soil spatial heterogeneity. In: Pankhurst, C. E. Doube, B. M., Gupta, V. V. S. R. and Grace, P. R. (Eds). Soil Biota. Management in Sustainable Farming Systems. CSIRO, Melbourne, Australia. pp 156-161.

Robertson, G. P., Crum, J. R. and Ellis, B. G., 1993. The spatial variability of soil resources following longterm disturbance. Oecologia 96, 451-456.

Robertson, G. P. and Freckman, D., 1995. The spatial distribution of nematode trophic groups across a cultivated ecosystem. Ecology 76, 1425-1432.

Rossi J.-P., 1998. Rôle fonctionnel de la distribution spatiale des vers de terre d'une savane humide de Côte d'Ivoire. Thèse de l'Université Pierre et Marie Curie - Paris 6, 192 p.

Rossi J.-P., The spatio-temporal variability of earthworm functional groups in a tropical grass savanna (Cote d'Ivoire). (in press).

Rossi J.-P. and Lavelle P., 1993. Statistical procedure for field surveys. In : Lavelle, P. (Ed). Conservation of Soil Fertility in Low-input Agricultural Systems by Manipulating Earthworm Communities. EC Project n ${ }^{\circ}$ ERBTS3*CT920128. Report nº 1. Chapter IX. pp 63-86.

Rossi J.-P. and Lavelle P. 1998. Earthworm aggregation in the savannas of Lamto (Côte d'Ivoire). Appl. Soil Ecol. 7, 195-199.

Rossi, J.-P. and Quénéhervé, P., 1998. Relating species density to environmental variables in presence of spatial autocorrelation. A study case on soil nematodes distribution. Ecography 21(2), 117-123.

Rossi, J.-P., Delaville, L. and Quénéhervé, P., 1996. Microspatial structure of a plant-parasitic nematode community in a sugarcane field in Martinique. Appl. Soil Ecol. 3, 17-26.

Rossi, J.-P., Lavelle, P. and Albrecht, A., 1997. Relationships between spatial pattern of the endogeic earthworm Polypheretima elongata and soil heterogeneity. Soil Biol. Biochem. 29 (3-4), 485-488.

Rossi, J.-P., Lavelle, P. and Tondoh, J. E., 1995. Statistical tool for soil biology. X. Geostatistical analysis. Eur. J. Soil Biol. 31 (4), 173-181.

Satchell, J. E. 1955., Some aspects of earthworm ecology. In: McKevan, D. K. (Ed). Soil Zoology. Butterworths, London, UK. pp. 180-201.

Stein, A., Bekker, R. M., Blom, J. H. C. and Rogaar, H. 1992., Spatial variability of earthworm populations in a permanent polder grassland. Biol. Fertil. Soils 14, 260-266.

Svendsen, J. A. 1957., The distribution of Lumbricidae in an area of Pennine moorland (Moor House Nature Reserve). J. Anim. Ecol. 26, 423-439.

Taylor, L. R. 1961., Aggregation, variance and the mean. Nature 189, 732-735. 
Taylor, L. R., 1984. Assessing and interpreting the spatial distribution of insect populations. Ann. Rev. Entomol. 29, 321-357.

Taylor, L. R., Woiwod, I. P. and Perry, J. N., 1978. The density-dependence of spatial behaviour and the rarity of randomness. J. Anim. Ecol. 47, 383-406.

Taylor, L. R., Perry, J. N., Woiwod, I. P. and Taylor, R. A. J., 1988. Specificity of the spatial power-law exponent in ecology and agriculture. Nature 332, 721-722.

Tilman, D., 1988. Plant Strategies and the Dynamics and Structure of Plant Communities. Princeton University Press, Princeton.

Wallace, M. K. and Hawkins, D. M., 1994. Application of geostatistics in plant nematology. J. Nematol. 26, 626-634.

Wallace, M. K., Rust, R. H., Hawkins, D. M. and MacDonald, D. H., 1993. Correlation of edaphic factors with plant-parasitic nematode population densities in a forage field. J. Nematol. 25, 642-653.

Wardle, D. and Lavelle, P., 1997. Linkages between Soil Biota, plant litter quality and decomposition. In: Cadisch, G. and Giller, K. E. (Eds). Driven by Nature. CAB International, Wallingford, UK. pp. 107 125.

Webster, R., 1985. Quantitative spatial analysis of soil in the field. Adv. Soil Sci. 3, 1-70.

Webster, R. and McBratney, A. B., 1989. On the Akaike Information Criterion for choosing models for variograms of soil properties. J. Soil Sci. 40, 493-496.

Webster, R. and Oliver, M. A., 1990. Statistical Methods in Soil and Land Resource Survey. Oxford University Press, London, UK. 316 p.

Yost, R. S., Trangmar, B. B., Ndiaye, J. P., and Yoshida, N. S., 1989. Geostatistical software for PC-DOS and MS-DOS. I. Semivariograms. Department of Agronomy and Soil Science, University of Hawaii, Honolulu, HA. 


\section{FIGURE CAPTIONS}

Fig. 1. Factorial map of the Principal Component Analysis (PCA) performed with some biometric variables and both aggregation indices employed.

Fig. 2. Projection of the objects (species in plots) onto the first two axes of the PCA.

Fig. 3. Spherical semivariogram obtained for Andiodrilus sp. in the pasture plot in June 1995.

Fig. 4. Contour maps of abundance $\left(\mathrm{N} \mathrm{m}^{-2}\right)$ of juveniles of Glossodrilus sp. at two different dates in the pasture plot. 


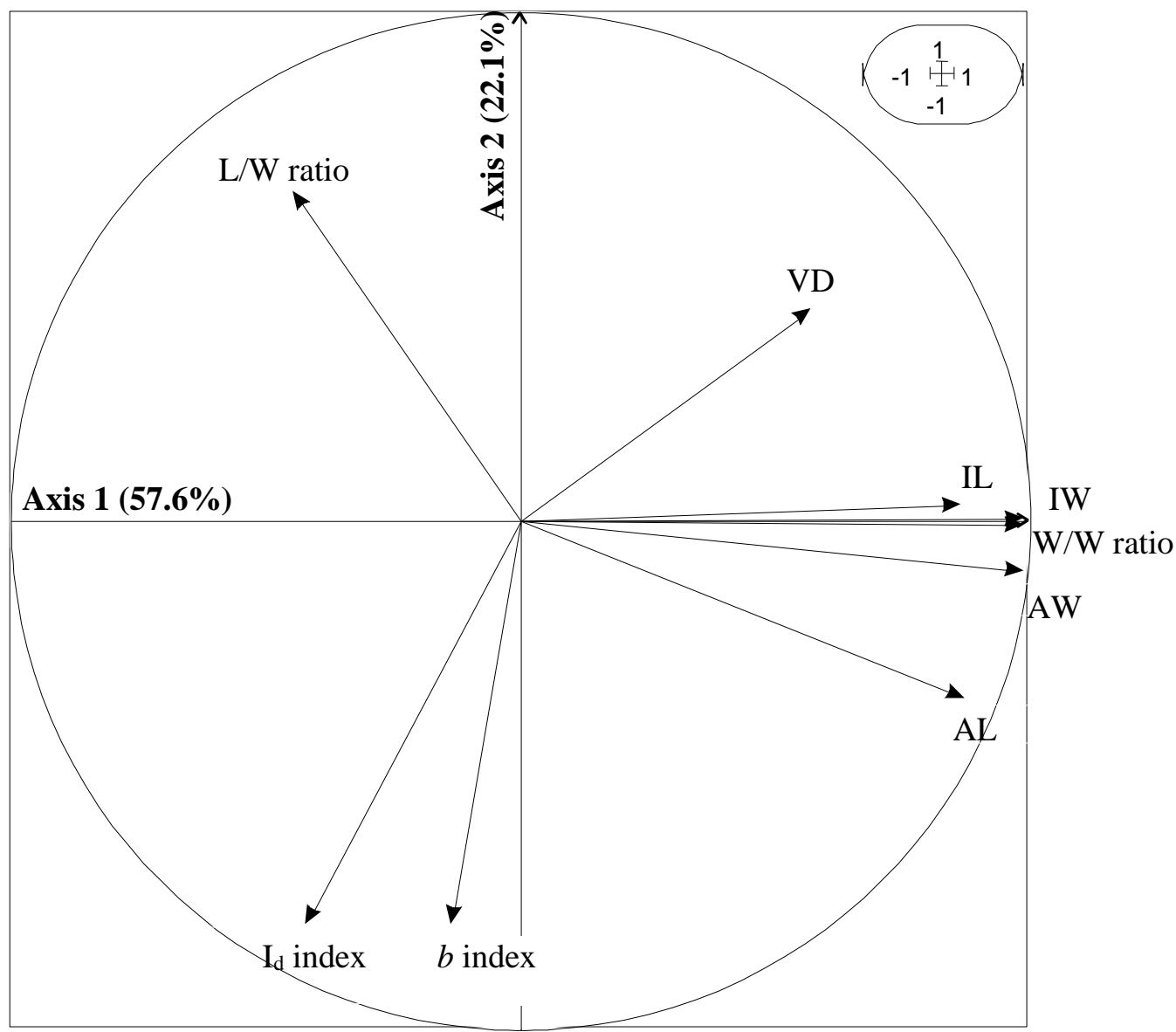

Figure 1 


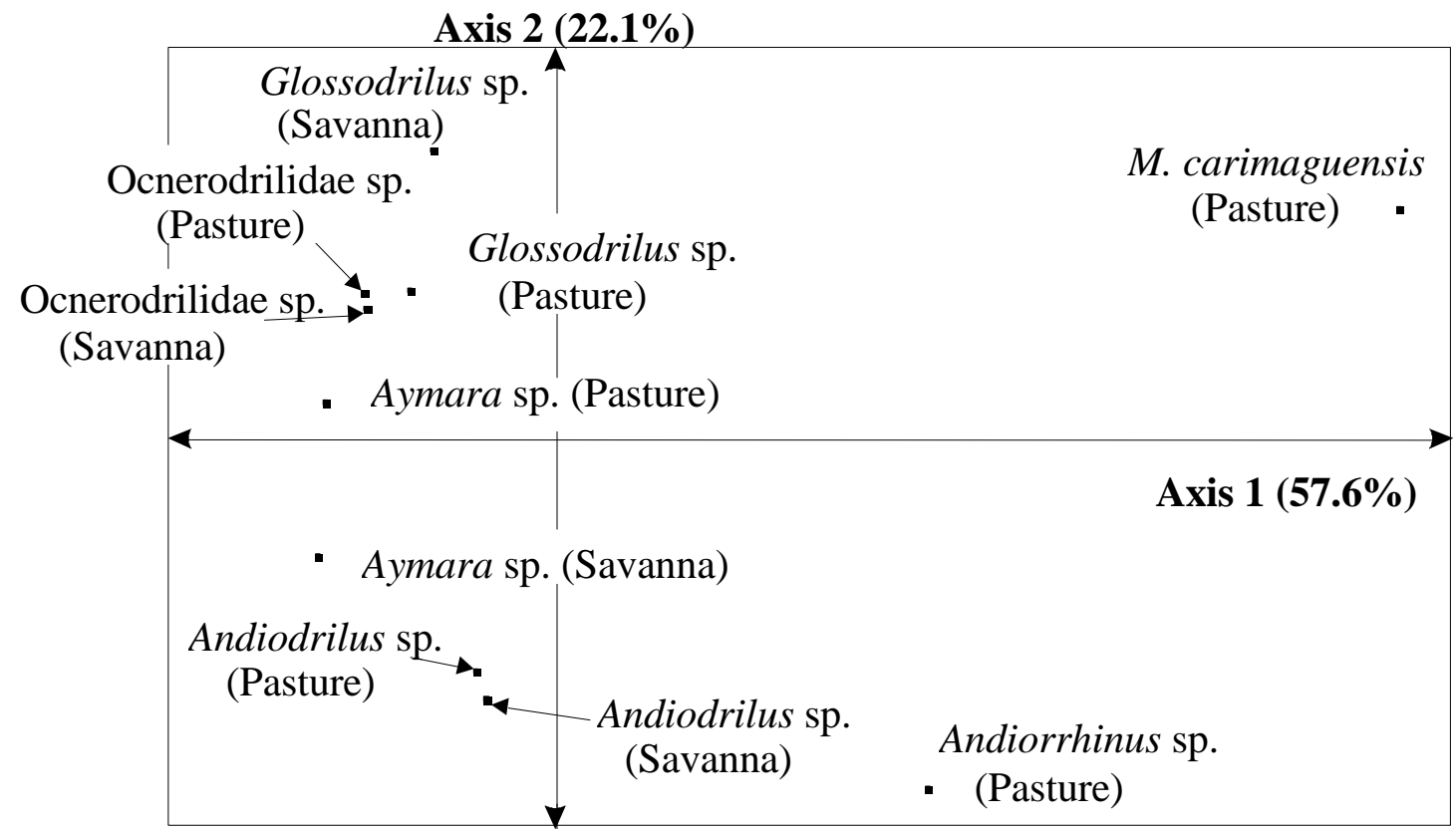

Figure 2 


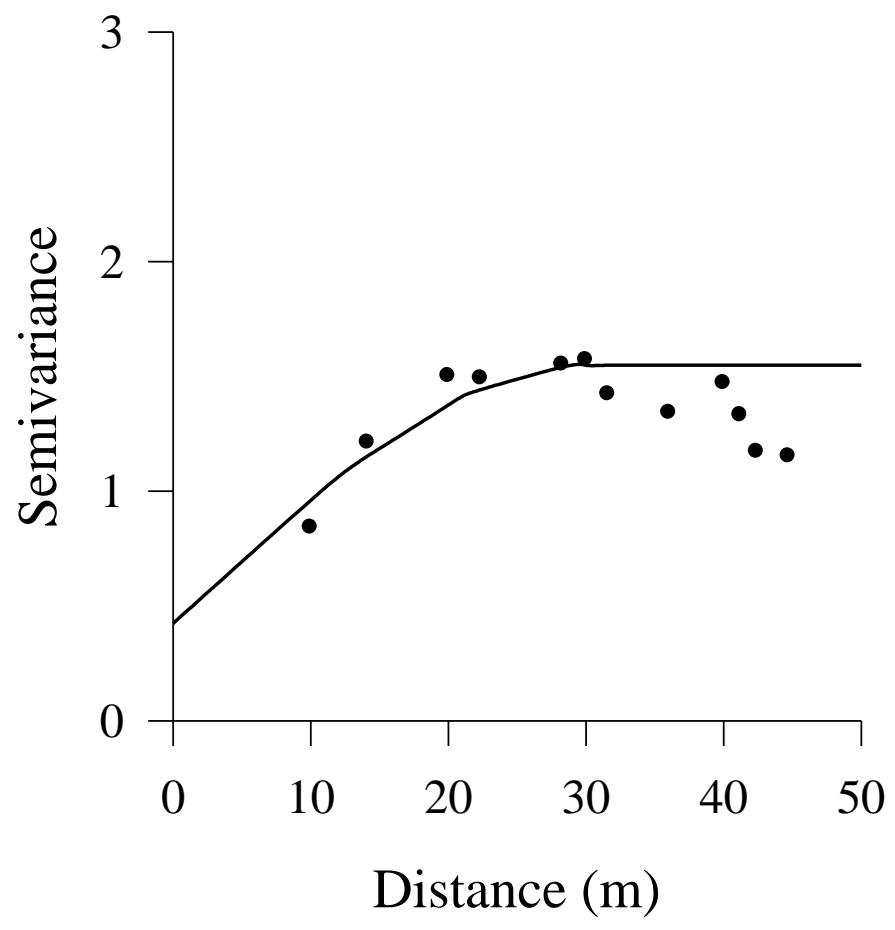

Figure 3 


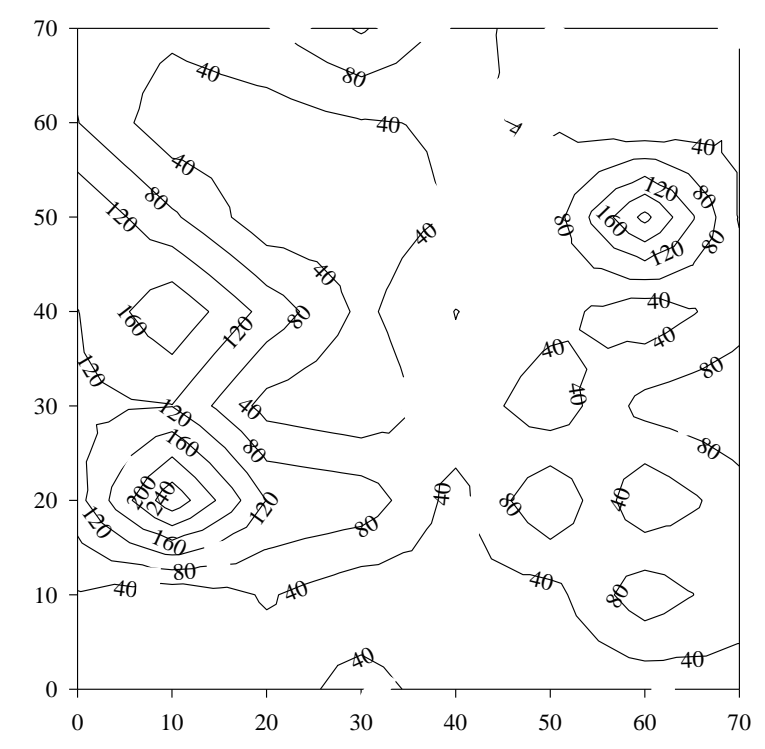

a)

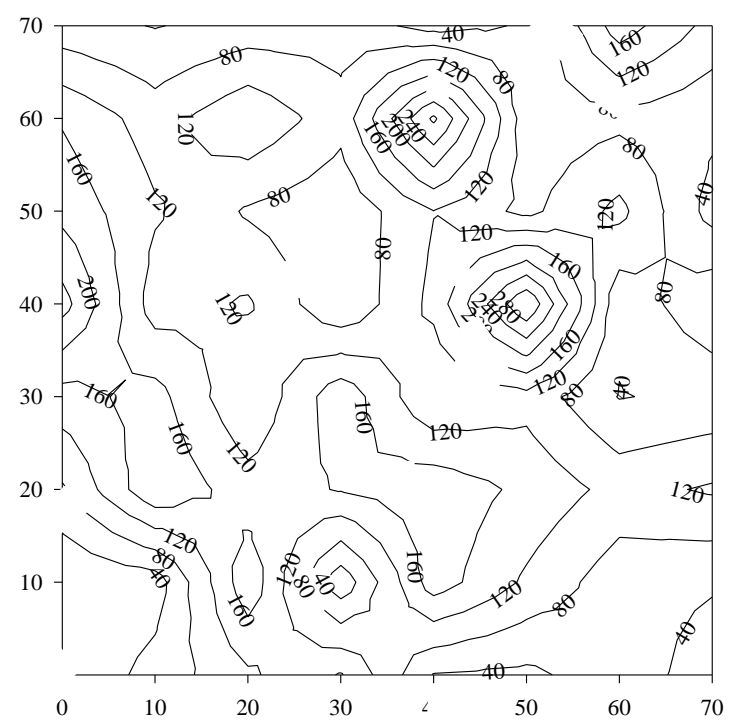

b)

Figure 4 


\section{TABLE CAPTIONS}

Table 1. Summary statistics of abundance of earthworms $\left(\mathrm{N} \mathrm{m}^{-2}\right)$ of the 64 points regular grid during three dates in the savanna. ${ }^{1}$

Table 2. Summary statistics of abundance of earthworms $\left(\mathrm{N} \mathrm{m}^{-2}\right)$ of the 64 points regular grid during three dates in the pasture. ${ }^{1}$

Table 3. Aggregation indices obtained for several earthworm species in the savanna and pasture plots.

Table 4. Models of the semivariograms and range $(\mathrm{m})$ obtained for each species during the whole study period. 
Table 1

\begin{tabular}{llcccccccccc}
\hline & & \multicolumn{3}{c}{ Date 1 } & \multicolumn{3}{c}{ Date 2 } & \multicolumn{3}{c}{ Date 3 } \\
\hline Species & Category & Mean & S.D. & $\begin{array}{c}\text { S. } \\
\text { error }\end{array}$ & Mean & S.D. & $\begin{array}{c}\text { S. } \\
\text { error }\end{array}$ & Mean & S.D. & $\begin{array}{c}\text { S. } \\
\text { error }\end{array}$ \\
\hline Andiodrilus sp. & Adults & 0.94 & 2.9 & 0.36 & 0.7 & 2.2 & 0.3 & 2.1 & 4.2 & 0.53 \\
& Juveniles & 1.03 & 2.9 & 0.37 & 2.1 & 3.7 & 0.5 & 0.4 & 1.5 & 0.18 \\
& Cocoons & 0 & 0 & 0 & 0.4 & 1.8 & 0.2 & 0.5 & 1.6 & 0.20 \\
Andiorrhinus sp. & Adults & 0 & 0 & 0 & 1.6 & 12.5 & 1.6 & 0.09 & 0.75 & 0.09 \\
& Juveniles & 0 & 0 & 0 & 0 & 0 & 0 & 0 & 0 & 0 \\
& Cocoons & 0 & 0 & 0 & 0 & 0 & 0 & 0 & 0 & 0 \\
Aymara sp. & Adults & 0 & 0 & 0 & 0 & 0 & 0 & 4.5 & 6.4 & 0.80 \\
& Juveniles & 0 & 0 & 0 & 1.36 & 3.6 & 0.4 & 3.3 & 5.3 & 0.67 \\
Glossodrilus sp. & Cocoons & 0 & 0 & 0 & 0 & 0 & 0 & 0 & 0 & 0 \\
& Adults & 19.3 & 19.6 & 2.5 & 14.3 & 17.2 & 2.2 & 0 & 0 & 0 \\
& Juveniles & 27.0 & 29.8 & 3.7 & 4.7 & 6.1 & 0.7 & 30.45 & 25.9 & 3.2 \\
M. carimaguensis & Cocoons & 3.9 & 7.2 & 0.9 & 0.3 & 1.8 & 0.2 & 0 & 0 & 0 \\
& Adults & 0 & 0 & 0 & 0.09 & 0.75 & 0.09 & 0.3 & 1.78 & 0.22 \\
& Juveniles & 0 & 0 & 0 & 0 & 0 & 0 & 0.39 & 1.92 & 0.24 \\
Ocnerodrilidae sp. & Cocoons & 0 & 0 & 0 & 0 & 0 & 0 & 0 & 0 & 0 \\
& Adults & 1.9 & 6.0 & 0.75 & 3.13 & 6.23 & 0.78 & 4.8 & 1.63 & 0.2 \\
& Juveniles & 0.09 & 0.75 & 0.09 & 0 & 0 & 0 & 2.1 & 8.3 & 1.03 \\
& Cocoons & 0 & 0 & 0 & 0 & 0 & 0 & 0 & 6.1 & 0.76 \\
\hline
\end{tabular}

${ }^{1}$ data from the spatially explicit sampling 
Table 2

\begin{tabular}{llcccccccccc}
\hline & & \multicolumn{3}{c}{ Date 1 } & \multicolumn{3}{c}{ Date 2 } & \multicolumn{3}{c}{ Date 3 } \\
\hline Species & Category & Mean & S.D. & $\begin{array}{c}\text { S. } \\
\text { error }\end{array}$ & Mean & S.D. & $\begin{array}{c}\text { S. } \\
\text { error }\end{array}$ & Mean & S.D. & $\begin{array}{c}\text { S. } \\
\text { error }\end{array}$ \\
\hline Andiodrilus sp. & Adults & 0.6 & 2.1 & 0.26 & 1.5 & 3.9 & 0.48 & 2.4 & 5.4 & 0.67 \\
& Juveniles & 2.9 & 5.6 & 0.70 & 2.9 & 6.5 & 0.82 & 3.8 & 9.6 & 1.2 \\
& Cocoons & 0 & 0 & 0 & 0.9 & 3.0 & 0.37 & 1.9 & 4.2 & 0.53 \\
Andiorrhinus sp. & Adults & 0.56 & 1.76 & 0.22 & 0 & 0 & 0 & 0.4 & 1.5 & 0.18 \\
& Juveniles & 0.84 & 2.36 & 0.29 & 0.2 & 1.0 & 0.13 & 0 & 0 & 0 \\
& Cocoons & 0 & 0 & 0 & 0 & 0 & 0 & 0 & 0 & 0 \\
Aymara sp. & Adults & 0 & 0 & 0 & 0.2 & 1.05 & 0.13 & 10.5 & 12.7 & 1.6 \\
& Juveniles & 0 & 0 & 0 & 0.3 & 1.28 & 0.16 & 3.0 & 5.8 & 0.7 \\
& Cocoons & 0 & 0 & 0 & 0.7 & 3.34 & 0.42 & 0.8 & 6.2 & 0.8 \\
Glossodrilus sp. & Adults & 6.9 & 9.4 & 1.18 & 34.3 & 22.0 & 2.7 & 0 & 0 & 0 \\
& Juveniles & 59.7 & 54.2 & 6.78 & 2.5 & 6.4 & 0.8 & 102.5 & 68.4 & 8.5 \\
& Cocoons & 0.2 & 1.0 & 0.13 & 0 & 0 & 0 & 0 & 0 & 0 \\
M. carimaguensis & Adults & 0.94 & 2.20 & 0.27 & 1.8 & 4.6 & 0.57 & 6.0 & 7.1 & 0.89 \\
& Juveniles & 0.09 & 0.75 & 0.09 & 0.1 & 0.7 & 0.09 & 8.5 & 10.4 & 1.30 \\
& Cocoons & 0 & 0 & 0 & 0 & 0 & 0 & 0 & 0 & 0 \\
Ocnerodrilidae sp. & Adults & 0 & 0 & 0 & 6.44 & 10.6 & 1.32 & 14.6 & 17.7 & 2.22 \\
& Juveniles & 0 & 0 & 0 & 0.2 & 1.62 & 0.20 & 4.2 & 8.2 & 1.02 \\
& Cocoons & 0 & 0 & 0 & 0 & 0 & 0 & 0 & 0 & 0 \\
\hline
\end{tabular}

${ }^{1}$ data from the spatially explicit sampling 
Table 3

\begin{tabular}{lcccccc}
\hline \multirow{2}{*}{ Species } & \multicolumn{2}{c}{ Morisita's index } & \multicolumn{2}{c}{$b$ Taylor } & Average & Standard \\
& Savanna & Pasture & Savanna & Pasture & value of $b$ & error \\
\hline Andiodrilus $\mathrm{sp}$. & $2.903^{*}$ & $3.396^{*}$ & 1.889 & 1.704 & 1.797 & 0.131 \\
Andiorrhinus $\mathrm{sp}$. & $\mathrm{ND}^{\mathrm{II}}$ & $3.759^{*}$ & $\mathrm{ND}$ & 1.801 & 1.801 & $\mathrm{ND}$ \\
Aymara sp. & $3.722^{*}$ & $3.505^{*}$ & 1.634 & 1.385 & 1.510 & 0.176 \\
Glossodrilus $\mathrm{sp}$. & $1.833^{*}$ & $2.160^{*}$ & 1.476 & 1.615 & 1.546 & 0.098 \\
M. carimaguensis & $4.857^{*}$ & $1.137^{*}$ & 1.542 & 1.405 & 1.474 & 0.097 \\
Ocnerodrilidae sp. & $2.604^{*}$ & $2.234^{*}$ & 1.579 & 1.603 & 1.591 & 0.017 \\
\hline
\end{tabular}

" $\mathrm{ND}=$ Not determined

* Values statistically different from randomness (Chi-square test) 


\section{Table 4}

\begin{tabular}{|c|c|c|c|c|c|c|c|}
\hline \multirow[b]{2}{*}{ Species name } & \multirow{2}{*}{$\begin{array}{c}\text { Demographic } \\
\text { stage }\end{array}$} & \multicolumn{3}{|c|}{ Native savanna } & \multicolumn{3}{|c|}{ Introduced pasture } \\
\hline & & 1993 & 1994 & 1995 & 1993 & 1994 & 1995 \\
\hline \multirow[t]{3}{*}{ Andiodrilus sp. } & Adults & - & - & $\begin{array}{c}\text { Spherical } \\
44.7\end{array}$ & - & $\begin{array}{c}\text { Spherical } \\
28.7\end{array}$ & $\begin{array}{c}\text { Spherical } \\
54.5\end{array}$ \\
\hline & Juveniles & - & - & - & - & $\begin{array}{c}\text { Spherical } \\
27.1\end{array}$ & $\begin{array}{c}\text { Spherical } \\
30.3\end{array}$ \\
\hline & Cocoons & - & - & - & - & - & $\begin{array}{c}\text { Spherical } \\
32.1\end{array}$ \\
\hline \multirow[t]{3}{*}{ Aymara sp. } & Adults & - & - & $\begin{array}{c}\text { Spherical } \\
41.2\end{array}$ & - & - & - \\
\hline & Juveniles & - & - & Linear & - & - & - \\
\hline & Cocoons & - & - & - & - & - & - \\
\hline \multirow[t]{3}{*}{ Glossodrilus sp. } & Adults & $\begin{array}{c}\text { Spherical } \\
37.2\end{array}$ & - & - & Linear & - & - \\
\hline & Juveniles & $\begin{array}{c}\text { Spherical } \\
29.8\end{array}$ & $\begin{array}{c}\text { Spherical } \\
36.2\end{array}$ & - & - & $\begin{array}{c}\text { Spherical } \\
57.4\end{array}$ & $\begin{array}{c}\text { Spherical } \\
41.8\end{array}$ \\
\hline & Cocoons & Linear & - & - & - & - & - \\
\hline \multirow[t]{3}{*}{ Ocnerodrilidae sp. } & Adults & - & $\begin{array}{c}\text { Spherical } \\
30.9\end{array}$ & - & - & - & $\begin{array}{c}\text { Spherical } \\
30.8\end{array}$ \\
\hline & Juveniles & - & - & - & - & - & - \\
\hline & Cocoons & $\mathrm{ND}^{\Psi}$ & ND & ND & ND & ND & ND \\
\hline
\end{tabular}

\footnotetext{
${ }^{\Psi}$ ND: Not determined
}

—: Nugget variogram 